\title{
Eribulin for the treatment of metastatic breast cancer: an update on its safety and efficacy [Corrigendum]
}

\author{
Doherty MK, Morris PG. International Journal of Women's \\ Health. 2015;7:47-58.
}

On page 50, Table 1, Note section, "MTD $2 \mathrm{mg} / \mathrm{m}^{2}$ but $1.4 \mathrm{mg} / \mathrm{m}^{2}$ recommended for subsequent studies". Should have been included.

On page 50 , Table 2 , the 4 th column heading should have been "Patients", and the 5th column heading should have been "Median Prior Chemotherapy Regimens".

On page 51, paragraph 4, the sentence "Overall, peripheral neuropathy was observed in $31(59.6 \%)$ patients at any grade" should have been "Overall, peripheral neuropathy was observed in $36(59.6 \%)$ patients at any grade".
On page 54, Future directions heading, 1st paragraph, "A Phase III study comparing eribulin with paclitaxel in the first-line and second-line treatment of HER2-negative $\mathrm{MBC}$ is currently recruiting patients in centers in the USA. ${ }^{~}{ }^{56}$ Should have cited reference 58.

On page 54, Future directions heading, 1st paragraph, "For HER2-positive MBC, taxanes combined with trastuzumab have yielded ORRs of $69 \%-76 \%$ and median PFS rates of 9-12 months." ${ }^{\text {41,42 }}$ Should have been "For HER2positive $\mathrm{MBC}$, taxanes combined with trastuzumab have yielded ORRs of $69 \%-76 \%$ and median TTP rates of $9-12$ months." ${ }^{\prime 1,42}$
International Journal of Women's Health

\section{Publish your work in this journal}

The International Journal of Women's Health is an international, peerreviewed open-access journal publishing original research, reports, editorials, reviews and commentaries on all aspects of women's healthcare including gynecology, obstetrics, and breast cancer. The manuscript management system is completely online and includes

\section{Dovepress}

a very quick and fair peer-review system, which is all easy to use. Visit http://www.dovepress.com/testimonials.php to read real quotes from published authors. 